University of Wollongong

Research Online

Australian Institute for Innovative Materials -

Papers

Australian Institute for Innovative Materials

$1-1-2010$

Synthesis and electrochemical studies on $\mathrm{Li} 2 \mathrm{CuSnO} 4$ and $\mathrm{Li} 2 \mathrm{CuSnSiO} 6$ as negative electrode in lithium batteries

Atef Y. Shenouda

Central Metallurgical Research and Development Institute

Hua-Kun Liu

University of Wollongong, hua@uow.edu.au

Follow this and additional works at: https://ro.uow.edu.au/aiimpapers

Part of the Engineering Commons, and the Physical Sciences and Mathematics Commons

Research Online is the open access institutional repository for the University of Wollongong. For further information contact the UOW Library: research-pubs@uow.edu.au 


\title{
Synthesis and electrochemical studies on Li2CuSnO4 and Li2CuSnSiO6 as negative electrode in lithium batteries
}

\author{
Abstract \\ $\mathrm{Li}_{2} \mathrm{CuSnO}_{4}$ and $\mathrm{Li}_{2} \mathrm{CuSnSiO} 6$ were prepared from their precursors compounds using Brij surfactant and a \\ hydrothermal autoclave method. X-ray diffraction characterization revealed that the crystal structures of \\ these compounds were tetragonal. Scanning electron microscope investigation showed the particle size \\ morphology of $\mathrm{Li}_{2} \mathrm{CuSnSiO}_{6}$ is larger than that of $\mathrm{Li}_{2} \mathrm{CuSnO}_{4}$. Electrochemical impedance spectroscopy \\ (EIS) explained that $\mathrm{Li}_{2} \mathrm{CuSnO}_{4}$ cell had higher charge transfer resistance $\left(\mathrm{R}_{\mathrm{Ct}}=2936 \Omega\right)$ than that of \\ $\mathrm{Li}_{2} \mathrm{CuSnSiO}_{6}(38 \Omega)$. Furthermore, the reversible specific discharge capacity of the $\mathrm{Li}_{2} \mathrm{CuSnSiO}_{6}$ cell was \\ $870 \mathrm{mAh} / \mathrm{g}$ in comparison with $780 \mathrm{mAh} / \mathrm{g}$ for the $\mathrm{Li}_{2} \mathrm{CuSnO}_{4}$ cell after 100 cycles. \\ Keywords \\ Synthesis, electrochemical, studies, Li2CuSnO4, Li2CuSnSiO6, negative, electrode, lithium, batteries \\ Disciplines \\ Engineering | Physical Sciences and Mathematics \\ Publication Details \\ Shenouda, AY \& Liu, HK (2010), Synthesis and electrochemical studies on $\mathrm{Li}_{2} \mathrm{CuSnO}_{4}$ and $\mathrm{Li}_{2} \mathrm{CuSnSiO}_{6}$ as \\ negative electrode in lithium batteries, Rechargeable Lithium and Lithium-Ion Batteries - 216th ECS \\ Meeting, pp. 75-89, Pennington, NJ, USA: The Electrochemical Society.
}

This journal article is available at Research Online: https://ro.uow.edu.au/aiimpapers/73 


\title{
Synthesis and Electrochemical Studies on $\mathrm{Li}_{2} \mathrm{CuSnO}_{4}$ and $\mathrm{Li}_{2} \mathrm{CuSnSiO}_{6}$ as negative electrode in the lithium batteries
}

\author{
Atef Y. Shenouda ${ }^{\text {a, }}$ and Hua Kun Liu ${ }^{b}$ \\ a Central Metallurgical Research and Development Institute (CMRDI), \\ Tebbin, P.O. Box 87 Helwan, Egypt. \\ b Institute for Superconducting and Electronic Materials, ARC Centre of \\ Excellence for Electro materials Science, University of Wollongong, NSW 2522, \\ Australia
}

\begin{abstract}
$\mathrm{Li}_{2} \mathrm{CuSnO}_{4}$ and $\mathrm{Li}_{2} \mathrm{CuSnSiO}_{6}$ were prepared from their precursors compounds using Brij surfactant and a hydrothermal autoclave method. . X-ray diffraction characterization revealed that the crystal structures of these compounds were tetragonal. Scanning electron microscope investigation showed the particle size morphology of $\mathrm{Li}_{2} \mathrm{CuSnSiO}_{6}$ is larger than that of $\mathrm{Li}_{2} \mathrm{CuSnO}_{4}$. Electrochemical impedance spectroscopy (EIS) explained that $\mathrm{Li}_{2} \mathrm{CuSnO}_{4}$ cell had higher charge transfer resistance $\left(\mathbf{R}_{\mathbf{c t}}=\right.$ 2936 $\Omega$ ) than that of $\mathrm{Li}_{2} \mathrm{CuSnSiO}_{6}$ (38 $\Omega$ ). Furthermore, the reversible specific discharge capacity of the $\mathrm{Li}_{2} \mathrm{CuSnSiO}_{6}$ cell was $870 \mathrm{mAh} / \mathrm{g}$ in comparison with $780 \mathrm{mAh} / \mathrm{g}$ for the $\mathrm{Li}_{2} \mathrm{CuSnO}_{4}$ cell after 100 cycles.
\end{abstract}

${ }^{*}$ Corresponding author:

- $\quad$ Tel: 0020225010642 /3 Fax: 0020225010639

- $\quad$ E-mail: ayshenouda@yahoo.com 


\section{Introduction}

Rechargeable lithium batteries have been considered an attractive power source for a wide variety of applications in popular electronic devices such as mobile telephones, video tape recorders and laptop computers. Nowadays, these batteries are being scaled-up for prospective use in electric vehicles and energy storage. Therefore, the development of lithium batteries into advanced utilities is considered an important goal to meet a great demand. Different types of active materials have been investigated for both positive and negative electrodes [1-8].

In order to develop high capacity anode for lithium ion batteries, silicon and some metals that can alloy with lithium at a high molar ratio are being exploited and developed as promising anode materials [9].

Fine powders of tin oxide doped with traces of silicon in combination with highly dispersed amorphous silicon oxide have been synthesized by an advanced ultrasonic spray method [10]. The electrochemical results showed that addition of silicon decreases the tin oxidation state, and hence, reduces the irreversible capacity during the first discharge/charge cycle. $\mathrm{SiO}_{2}$ and $\mathrm{Li}_{2} \mathrm{SiO}_{3}$ appeared during the first discharge, as confirmed by infrared (IR) spectroscopy. Furthermore, a reversible capacity was found of $900 \mathrm{mAh} / \mathrm{g}$ to $950 \mathrm{mAh} / \mathrm{g}$ for these composites. This improved performance was due to enhanced interfacial diffusion caused by highly dispersed inert second phases, i.e., $\mathrm{SiO}_{2}$ and $\mathrm{LiSi}_{2} \mathrm{O}_{3}$. It was found that when the silicon content in the precursor was high enough, some metallic tin appeared in the product. This means that addition of some $\mathrm{SiO}_{2}$ to the precursor will reduce the oxygen content of the final product. Since the oxygen bound to $\mathrm{Sn}$ is responsible for the observed irreversible capacity, a low oxidation state is highly beneficial for this anode material.

We can also see that the introduction of $\mathrm{SiO}_{2}$ into the $\mathrm{Li}_{2} \mathrm{O}-\mathrm{CuO}-\mathrm{SnO}_{2}$ system will improve the specific capacity through the intercalation and de-intercalation of $\mathrm{Li}$ with $\mathrm{Si}$. This study is an attempt to study the electrochemical performance of this quaternary metal oxide system $\left(\mathrm{Li}_{2} \mathrm{O}-\mathrm{CuO}-\mathrm{SnO}_{2}-\mathrm{SiO}_{2}\right)$. Also, the amount of reported literature on this system is small, and more data are needed.

\section{Experimental}

\subsection{Materials preparation}

Stoichiometric amounts of $\mathrm{CH}_{3} \mathrm{COOLi}$ (Alfa Aesar), $\left(\mathrm{CH}_{3} \mathrm{CO}_{2}\right)_{2} \mathrm{Cu}$ (Aldrich), and stannous oxalate (Aldrich) were dissolved separately in distilled water to prepare $\mathrm{Li}_{2} \mathrm{CuSnO}_{4}$. Brij $30\left[\mathrm{CH}_{3}\left(\mathrm{CH}_{2}\right)_{10} \mathrm{CH}_{2}\left(\mathrm{OCH}_{2} \mathrm{CH}_{2}\right)_{4} \mathrm{OH}\right]$ surfactant was added in a weight ratio of 5: $1 \mathrm{wt}$. / wt. with respect to the active materials. In order to prepare $\mathrm{Li}_{2} \mathrm{CuSnSiO}_{6}$, we used $\mathrm{Si}_{3} \mathrm{~N}_{4}$ (Nanostructured and Amorphous materials Inc., USA, $15 \mathrm{~nm}$ ). The raw material compounds were then mixed together. The mixed solution was stirred and heat-treated at $80^{\circ} \mathrm{C}$ for 2 hours. The mixture was then transferred to an autoclave vessel $\left(250 \mathrm{~cm}^{3}\right)$ and heat-treated at $250^{\circ} \mathrm{C}$ for 10 hours. Finally, the samples were calcined in air atmosphere at $750^{\circ} \mathrm{C}$ for $12 \mathrm{~h}$ in an alumina crucible. The samples were left to cool down to room temperature inside the furnace. The samples were sintered again for another $12 \mathrm{~h}$ at the same temperature in air. 


\subsection{Materials characterisations}

Powder X-ray diffraction (XRD) measurements were carried out using a Philips powder diffractometer with $\mathrm{Cu} \mathrm{K}$ radiation. Infrared absorption spectra were recorded using a FT/IR-6300 type A Fourier transform infrared (FTIR) interferometer. Samples were ground to fine powders, mixed, and diluted with $\mathrm{KBr}$. The IR region examined was $400-4000 \mathrm{~cm}^{-1}$. Elemental compositions of the various tin oxide compounds were analysed by inductively coupled plasma (ICP, PerkinElmer Optima 2000 DV). Scanning electron microscopy (SEM) was conducted with a JEOL SEM Model 6460.

\subsection{Electrochemical measurements}

The homogeneous slurry used to form the electrodes was composed of $85 \mathrm{wt} \%$ active materials, $10 \mathrm{wt} \%$ acetylene black, and $5 \mathrm{wt} \%$ polyvinylidene fluoride (PVDF) binder dissolved in $\mathrm{N}$-methyl pyrrolidone (NMP) solvent. It was then spread onto $\mathrm{Cu}$ foil substrates. The area of each coated electrode was $1 \mathrm{~cm}^{2}$. The electrodes were dried in a vacuum oven under a vacuum pressure of 30 Torr at $110^{\circ} \mathrm{C}$ for $12 \mathrm{~h}$. The electrodes were then pressed at a pressure of $2000 \mathrm{~kg} / \mathrm{cm}^{2}$. The active material loading was about $4 \mathrm{mg}$ for each individual electrode. CR2032 coin cells were then assembled in an argon filled glove box (Mbraun, Unilab, Germany), using lithium metal foil as the counter electrode. The electrolyte was $1 \mathrm{M} \mathrm{LiPF} 6$ in a mixture of ethylene carbonate (EC) and dimethyl carbonate (DMC) (1:1 by volume, provided by MERCK). The cells were galvanostatically charged and discharged over a voltage range of $0.0-3 \mathrm{~V}$ using a current of $0.02 \mathrm{~A}$ for both processes. Cyclic voltammetry (CV) measurements were performed using a Multi-stat CHI660 Electrochemical Workstation at a $0.1 \mathrm{mVs}^{-1}$ scanning rate, and the potential windows were 0 and $3 \mathrm{~V}$ versus $\mathrm{Li} / \mathrm{Li}^{+}$electrode. The AC impedance measurement amplitude was $50 \mathrm{mV}$. The frequency range was $100 \mathrm{kHz}-10 \mathrm{mHz}$.

\section{Results and Discussion:}

\subsection{Structural Characterization}

X-ray diffraction patterns of the $\mathrm{Li}_{2} \mathrm{CuSnO}_{4}$ and $\mathrm{Li}_{2} \mathrm{CuSnSiO}_{6}$ samples showed suitable crystallinity, as shown in Fig. 1. Their structures were indexed to the tetragonal system using Rietveld analysis of the XRD pattern data with a standard software package. The refined unit cell parameters are $a=4.752 \AA, c=3.203 \AA$, and cell volume, $V=72.3285 \AA^{3}$ for $\mathrm{Li}_{2} \mathrm{CuSnO}_{4}$, while $a=4.913 \AA, c=3.375 \AA$, and cell volume, $V=81.4643 \AA^{3}$ for $\mathrm{Li}_{2} \mathrm{CuSnSiO}_{6}$. The crystallite sizes of $\mathrm{Li}_{2} \mathrm{SnCuO}_{4}$ and $\mathrm{Li}_{2} \mathrm{CuSnSiO}_{6}$ are 11.1836 and $28.2495 \mathrm{~nm}$, respectively, according to the DebyeScherrer equation [11]:

$\mathrm{L}=0.9 \lambda / \omega \cos \theta$

where $\theta$ and $w$ are the Bragg angle and the full width at half maximum, measured in radians, of each diffraction peak, respectively. Also, $\lambda$ is the X-ray wavelength, and $L$ is the effective particle or grain size. It is observed that the unit cell parameters of $\mathrm{Li}_{2} \mathrm{SnCuSiO}_{6}$ are greater in value than those of $\mathrm{Li}_{2} \mathrm{SnCuO}_{4}$. 
Fig. 2 shows a SEM image of the samples. The powders have an average crystal size between 50 and $100 \mathrm{~nm}$. In general, the particles have an interconnected network structure in the form of aggregates.

Fig. 3 displays FTIR spectra collected in the wave number range from 400 to $4000 \mathrm{~cm}^{-1}$. The bands at $1200,1080,790$, and $495 \mathrm{~cm}^{-1}$ are attributed to different vibrational modes of $\mathrm{Si}-\mathrm{O}-\mathrm{Si}$ and $\mathrm{O}-\mathrm{Si}-\mathrm{O}$ groups; the vibration band at $625 \mathrm{~cm}^{-1}$ indicates an interaction between $\mathrm{Sn}, \mathrm{O}$, and $\mathrm{Si}$, which is equivalent to a $\mathrm{Sn}-\mathrm{O}-\mathrm{Si}$ bond in the silicon doped tin oxide composite. These data are consistent with previous literature [12].

\subsection{Electrochemical Impedance Spectra measurements}

Electrochemical impedance spectroscopy (EIS) may be considered as one of the most sensitive tools for the study of differences in electrode behavior due to surface modification. The electrochemical impedance spectra of the cells, as presented in Fig. 4, show an intercept at high frequency on the real axis $Z^{\prime}$ for the resistance of the electrolyte, $R_{e}$, followed by a semicircle in the high-middle frequency region, and a straight line in the low frequency region. The numerical value of the diameter of the semicircle on the $Z_{\text {real }}$ axis is approximately equal to the charge transfer resistance, $R_{\mathrm{ct}}$, and therefore, it can be seen that there is a marked decrease in $R_{\mathrm{ct}}$ after addition of the silicon compound. The straight line in the low frequency region is attributed to the diffusion of the lithium ions into the bulk of the electrode material, or the so-called Warburg diffusion. The plot of the real part of the impedance, $Z$ re, versus the reciprocal root square of the lower angular frequencies is displayed in Fig. 5. The straight lines are attributed to the diffusion of the lithium ions into the bulk of the electrode material, or the so-called Warburg diffusion. It is observed that the Warburg impedance coefficient, $\sigma_{\mathrm{w}}$ is $652.82 \Omega . \mathrm{cm}^{2} . \mathrm{s}^{-0.5}$ for the $\mathrm{Li}_{2} \mathrm{SnCuSiO}_{6}$ cell and it has a lower value than $\mathrm{Li}_{2} \mathrm{SnCuO}_{4}: 1415.839 \Omega . \mathrm{cm}^{2} . \mathrm{s}^{-0.5}$. The parameters of the equivalent circuit are presented in Table 1. Also, the diffusion coefficient values for the diffusion of the lithium ions into the bulk electrode materials have been calculated and recorded in Table 1[13].

The obtained diffusion coefficient $\left(8.31 \times 10^{-14} \mathrm{~cm}^{2} \mathrm{~s}^{-1}\right)$ for the $\mathrm{Li}_{2} \mathrm{SnCuSiO}_{6}$ cell explains the higher mobility for $\mathrm{Li}^{+}$ion diffusion than in the other cell, which lacked $\mathrm{Si}$. Furthermore, the exchange current density $\left(\mathrm{i}^{\circ}\right)$ of the $\mathrm{Li}_{2} \mathrm{SnCuSiO}_{6}$ cell $\mathrm{b}$ is higher the other cell a. Therefore, the charge-transfer reaction of $\mathrm{Li}_{2} \mathrm{SnCuSiO}_{6}$ electrode is stronger than in the other electrode prepared for the $\mathrm{Li}_{2} \mathrm{SnCuO}_{4}$ cell a. It is observed that the double layer capacitance $\left(\mathrm{C}_{\mathrm{dl}}\right)$ of cell $\mathrm{b}$ also has a higher value: $1.95 \times 10^{-5} \mathrm{~F}$.

Cyclic voltammetric measurements were carried out between 0 and $3 \mathrm{~V}$ as shown in Fig.6. The cyclic voltammograms of the investigated samples show a cathodic reduction peak in the range of $0.51-0.63 \mathrm{~V}$. This peak is attributed to intercalation of lithium into tin to form $\mathrm{Li}_{x} \mathrm{Sn}$ compound $(1 \leq x \leq 4.4)$ as observed in the literatures $[3,10]$. As we have $\mathrm{Li}_{2} \mathrm{SnCuO}_{4}$ and $\mathrm{Li}_{2} \mathrm{SnCuSiO}_{6}$ as starting materials, therefore the reduced form will be $\mathrm{Li}_{2} \mathrm{SnCu}$ and $\mathrm{Li}_{2} \mathrm{SnCuSi}$ compounds and their intercalation with $\mathrm{Li}^{+}$will be as follows $[14,15]$ :

$$
\begin{aligned}
& \mathrm{Li}_{2} \mathrm{SnCu}+(2.4-\mathbf{x}) \mathrm{Li}^{+}+4 \mathrm{e} \rightarrow \mathrm{Li}_{4.4-\mathrm{x}} \mathrm{Sn}+\mathrm{Cu} \\
& \mathrm{Li}_{2} \mathrm{SnCuSi}+(2.4-\mathbf{x}) \mathrm{Li}^{+}+4 \mathrm{e} \rightarrow \mathrm{Li}_{4.4-\mathrm{x}} \mathrm{Sn}+\mathrm{Cu}+\mathrm{Si} \\
& \mathrm{Si}+\mathrm{x} \mathrm{Li}^{+}+\mathrm{xe} \rightarrow \mathrm{Li}_{\mathrm{x}} \mathrm{Si}
\end{aligned}
$$


$\mathrm{Li}_{2} \mathrm{SnCuO}_{4}$ shows three anodic oxidation peaks at $0.42,0.85$ and $1.7 \mathrm{~V}$, respectively for the following reactions $[7,14,15]$.

$$
\begin{array}{ll}
\mathrm{Li}_{4.4-\mathrm{x}} \mathrm{Sn}+\mathrm{Cu} \rightarrow \mathrm{Li}_{2} \mathrm{SnCu}+(2.4-\mathrm{x}) \mathrm{Li}^{+}+2 \mathrm{e} & \mathrm{E}=0.42 \mathrm{~V} \\
\mathrm{Li}_{2} \mathrm{SnCu}+1.5 \mathrm{O}_{2} \rightarrow \mathrm{Li}_{2} \mathrm{SnCuO}_{3}+2 \mathrm{e} & \mathrm{E}=0.85 \mathrm{~V} \\
\mathrm{Li}_{2} \mathrm{SnCuO}_{3}+0.5 \mathrm{O}_{2} \rightarrow \mathrm{Li}_{2} \mathrm{SnCuO}_{4}+2 \mathrm{e} & \mathrm{E}=1.7 \mathrm{~V}
\end{array}
$$

$\mathrm{Li}_{2} \mathrm{SnCuSiO}_{6}$ shows three anodic oxidation peaks at $0.68,1.05$ and $1.85 \mathrm{~V}$ for the deintercalation of $\mathrm{Li}^{+}$from $\mathrm{Li}_{4.4-\mathrm{x}} \mathrm{Sn}$ and the oxidation of $\mathrm{Li}_{2} \mathrm{SnCuSi}$ to $\mathrm{Li}_{2} \mathrm{SnCuSiO}_{4}$ and $\mathrm{Li}_{2} \mathrm{SnCuSiO}_{6}$, respectively. It is observed that there is a shift in the anodic peaks to more positive potentials. This can be attributed to the oxidation of $\mathrm{Si}$ to $\mathrm{Si}^{(2-\mathrm{x})^{+}}$and $\mathrm{Si}^{4+}[15]$.

The first discharge capacity plateaus versus the working voltage between 3 and $0.0 \mathrm{~V}$ are illustrated in Fig. 7 . The profiles for the first reduction look fairly similar for the two samples. There is a plateau that falls in the range between 1.5 and $1.7 \mathrm{~V}$ vs. $\mathrm{Li}^{+}$for the reduction of $\mathrm{Li}_{2} \mathrm{SnCuO}_{4}$ to $\mathrm{Li}_{2} \mathrm{SnCuO}_{3}$ and $\mathrm{Li}_{2} \mathrm{SnCuSiO}_{6}$ to $\mathrm{Li}_{2} \mathrm{SnCuSiO}_{4}$. The region between 1 to $0.8 \mathrm{~V}$ is matching with the reduction of $\mathrm{Li}_{2} \mathrm{SnCuO}_{3}$ to $\mathrm{Li}_{2} \mathrm{SnCuO}_{2}$ and the similar $\mathrm{Si}$ compounds. The second plateau in the region of $0.4-0.7 \mathrm{~V}$ for the reduction of $\mathrm{Li}_{2} \mathrm{SnCuO}_{2}$ to $\mathrm{Li}_{2} \mathrm{SnCu}$ and the analogue compund $\mathrm{Li}_{2} \mathrm{SnCuSi}$. Below $0.4 \mathrm{~V}$, the intercalation of $\mathrm{Li}_{2} \mathrm{SnCu}$ or $\mathrm{Li}_{2} \mathrm{SnCuSi}$ with $\mathrm{Li}$ ions takes place and $\mathrm{Li}_{4.4-\mathrm{x}} \mathrm{Sn}$ is formed as mentioned before $[14,15]$.

The first discharge curve of cell " $b$ " delivers the highest specific discharge capacity of about $1300 \mathrm{mAh} \mathrm{g}^{-1}$. Similar results have been observed in the literature in spite of using different methods of preparation $[7,12,16]$. The cycling performance of these cells, as shown in Fig. 8, remained good for 140 cycles. The specific discharge capacity of the $\mathrm{Li}_{2} \mathrm{SnCuSiO}_{6}$ cell (b) is about $900 \mathrm{mAh} \mathrm{g}$, and it is higher than for cell (a). However, the discharge capacities have small decrease up to 140-150 cycles, and then followed by great decrease up to 200 cycles or more extra cycles. The excess capacity of $\mathrm{Li}_{2} \mathrm{CuSnO}_{4}$ and $\mathrm{Li}_{2} \mathrm{CuSnSiO}_{6}$ electrodes rather than $\mathrm{Sn}$ ones is attributed to the presence of $\mathrm{Cu}$ and $\mathrm{Si}$. Probably, the formation of the $\mathrm{Li}_{2} \mathrm{SnCu}$ or $\mathrm{Li}_{2} \mathrm{SnCu} \mathrm{Si}$ intermetallic phase relaxed the cracking process to a certain degree and improved the cycle life of the electrode. In comparison with the Sn electrodes, the lasts exhibit great capacity fading upon cycling as explained by S. Gopukumar et. al. [17].

It has been reported that transition metal oxides show reversible Li storage behaviour [18]. In those cases, a transition metal can react with $\mathrm{Li}_{2} \mathrm{O}$ upon $\mathrm{Li}$ extraction, which means that the reduction reaction at potentials above $1 \mathrm{~V}$ vs. $\mathrm{Li} / \mathrm{Li}^{+}$ is reversible, which could contribute to a high reversible capacity [19].

It was reported that $\mathrm{Li}-\mathrm{O}$ bonds are not stable when the charging voltage is above $1.3 \mathrm{~V}$ vs. $\mathrm{Li} / \mathrm{Li}^{+}$[19]. Moreover, it was indicated that $\mathrm{Li}_{2} \mathrm{O}$ formation reaction is reversible for most of the metal compounds in view of their thermodynamics. The reversibility of this reaction from $\mathrm{LiX}\left(\right.$ e.g. $\left.\mathrm{Li}_{2} \mathrm{O}\right)$ and metal (e.g. Ni) back to metal compounds is mainly influenced by the intrinsic conductivity of the MX compound, the grain size of LiX, the metal, the separation distance between LiX and metal and the electronic contact with the conductive additive [20]. 


\section{References}

1. A. Y. Shenouda, Electrochimica Acta, 51, 5973 (2006).

2. A. Y. Shenouda and K.R. Murali., J. Power Sources, 176, 332 (2008).

3. A. Y. Shenouda and Hua K. Liu , J. Power Sources, 185, 1386 (2008).

4. A. Y. Shenouda, Hua K. Liu, J. Alloys and Compounds 477, 498 (2009).

5. A. Y. Shenouda and S. M. El-Sayed, J. Alloys and Compounds xxx, xxx (2010).

6. J. L. Shui, G. S. Jiang, S. Xie, C. H. Chen, Electrochim. Acta, 49, 2209 (2004).

7. Y. Yu, C. H. Chen, J. L. Shui, S. Xie, Angew. Chem. Int. Ed. 44, 7085 (2005).

8. Yan Yu, Chun-Hua Chen, Yi Shi, Advanced Materials 19, 993 (2007).

9. Z. Wen, K. Wang, L. Chen, J. Xie, Electrochem. Commun. 8, 1349 (2006).

10. H. Huang, E.M. Kelder, L. Chen , J. Schoonman, J. Power Sources 81-82, 362 (1999).

11. C. Matei Ghimbeu, R.C. van Landschoot, J. Schoonman, M. Lumbreras, J. European Ceramic Soc., 27, 207 (2007).

12.Y. Liang, J. Fan, X. Xia, Y. Luo, Z. Jia Electrochimica Acta, 52, 5891 (2007).

13. A.J. Bard, L.R. Faulkner, Electrochemical Methods, $2^{\text {nd }}$ ed., p.231, John Wiley \& Sons, New York (2001).

14. D.G. Kim, H.Kim, H. J. Sohn, T. Kang, J. Power Sources, 104, 221 (2002).

15. Q. Sun, B. Zhang, Zheng-Wen Fu, Applied Surface Science 254, 3774 (2008).

16.Y.I. Kim, W.H. Lee, H.S. Moon, K.S. Ji, S.H. Seong and J.W. Park, J. Power Sources, 101, 253 (2001).

17. A. Sivashanmugam, T. Prem Kumar, N.G. Renganathan, S. Gopukumar, M. Wohlfahrt-Mehrens , J. Garche, J. Power Sources 144, 197-203 (2005).

18. P. Poizot, S. Laruelle, S. Grugeon, L. Dupont, J.-M. Tarascon, Nature, 407, 496 (2000).

19. A.D'ebart, L. Dupont, P. Poizot, J.-B. Leriche, J. M. Tarascon, J. Electrochem. Soc. 148, A1266 (2001).

20. X.H. Huang, J.P. Tu, B. Zhang, C.Q. Zhang, Y. Li, Y.F. Yuan, H.M. Wu, J. Power Sources 161, 541 (2006). 
Table 1. Impedance parameters of the cells samples.

\begin{tabular}{|c|c|c|c|c|c|c|}
\hline Samples & $\begin{array}{c}R_{e} \\
{[\Omega]}\end{array}$ & $\begin{array}{c}\mathbf{R}_{\mathrm{ct}} \\
{[\Omega]}\end{array}$ & $\begin{array}{c}\sigma \\
{\left[\Omega . \mathrm{cm}^{2} \mathrm{~s}^{-0.5}\right]}\end{array}$ & $\begin{array}{c}\mathrm{D} \\
{\left[\mathrm{cm}^{2} \mathrm{~s}^{-1}\right]}\end{array}$ & $\begin{array}{c}\mathrm{C}_{\mathrm{d}} \\
{[\mathrm{F}]}\end{array}$ & $\begin{array}{c}\mathbf{i}^{\mathbf{0}} \\
{\left[\mathrm{mA} / \mathrm{cm}^{2}\right]}\end{array}$ \\
\hline $\mathrm{Li}_{2} \mathrm{CuSnO}_{4}$ & 730 & 2936 & 1415.839 & $1.77 \times 10^{-14}$ & $7.77 \mathrm{E}-07$ & $7.00 \mathrm{E}-06$ \\
\hline $\mathrm{Li}_{2} \mathrm{CuSnSiO}_{6}$ & 22 & 38 & 652.8277 & $8.31 \times 10^{-14}$ & $1.95 \mathrm{E}-05$ & $6.75 \mathrm{E}-04$ \\
\hline
\end{tabular}




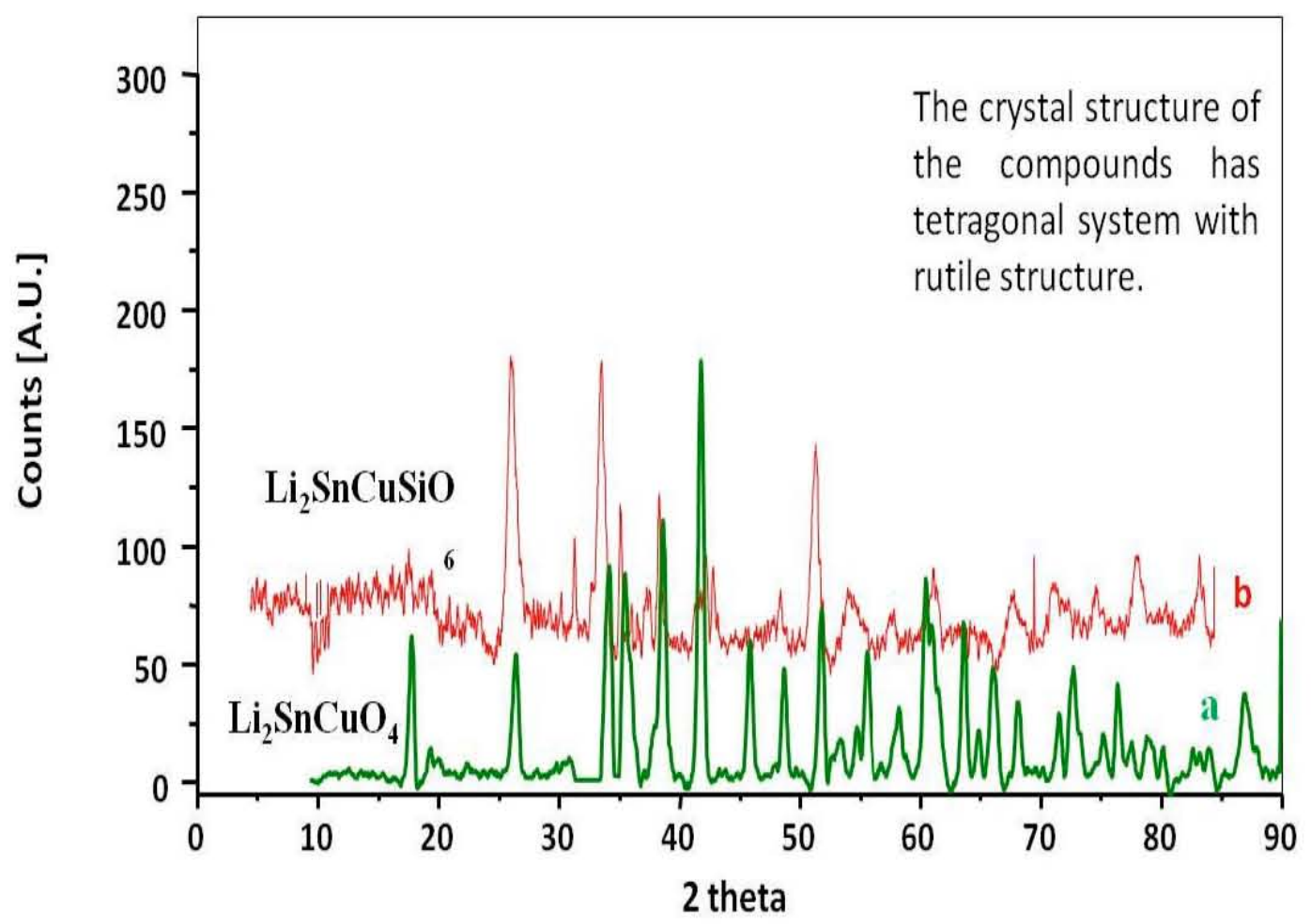

\section{Fig. 1 XRD patterns of (a) $\mathrm{Li}_{2} \mathrm{SnCuO}_{4}$ and (b) $\mathrm{Li}_{2} \mathrm{SiCuSnO}_{6}$ compounds.}




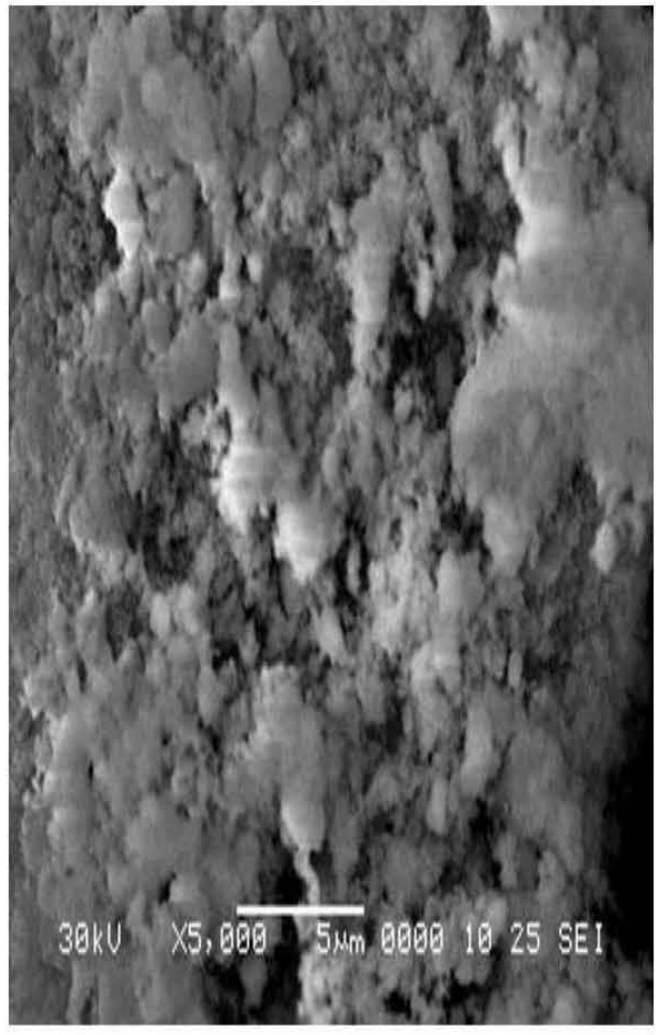

a

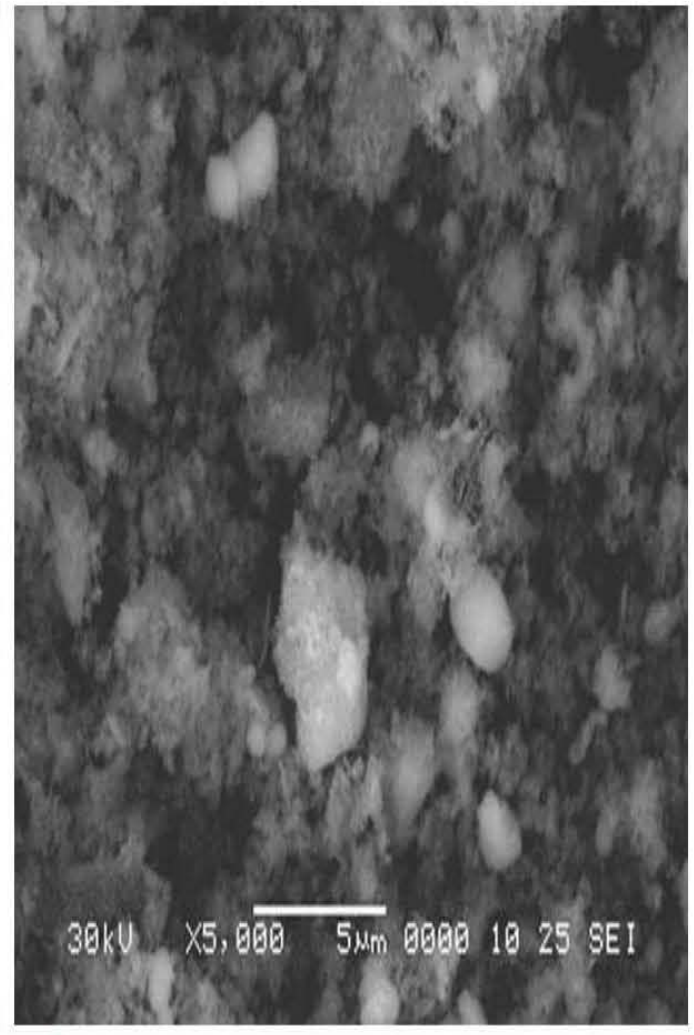

b

Fig.2 $\mathrm{SEM}$ of (a) $\mathrm{Li}_{2} \mathrm{SnCuO}_{4}$ and (b) $\mathrm{Li}_{2} \mathrm{SiCuSnO}_{6}$ compounds. 


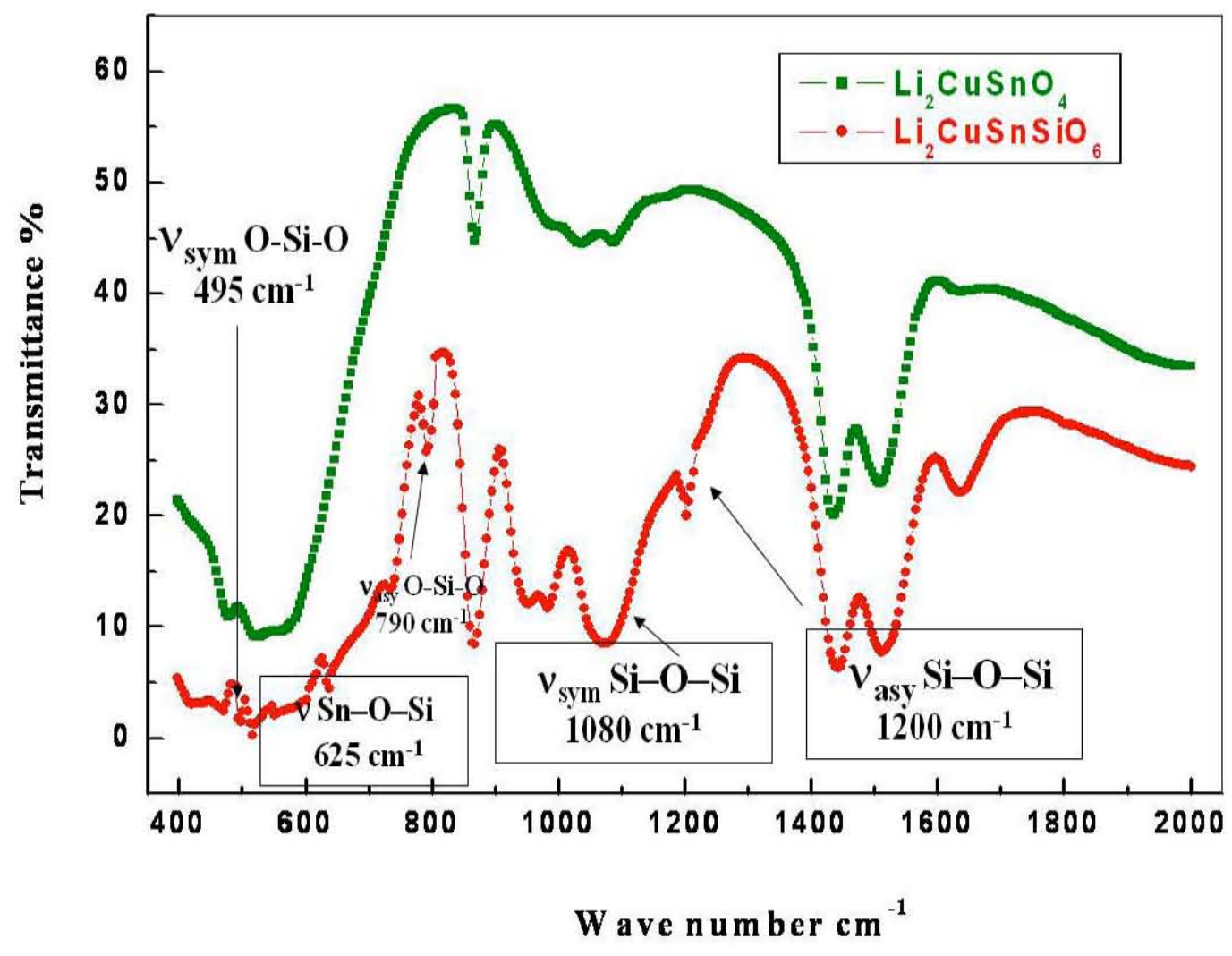

Fig. 3 FTIR spectra of the prepared (a) $\mathrm{Li}_{2} \mathrm{SnCuO}_{4}$ and (b) $\mathrm{Li}_{2} \mathrm{SiCuSnO}_{6}$ compounds. 


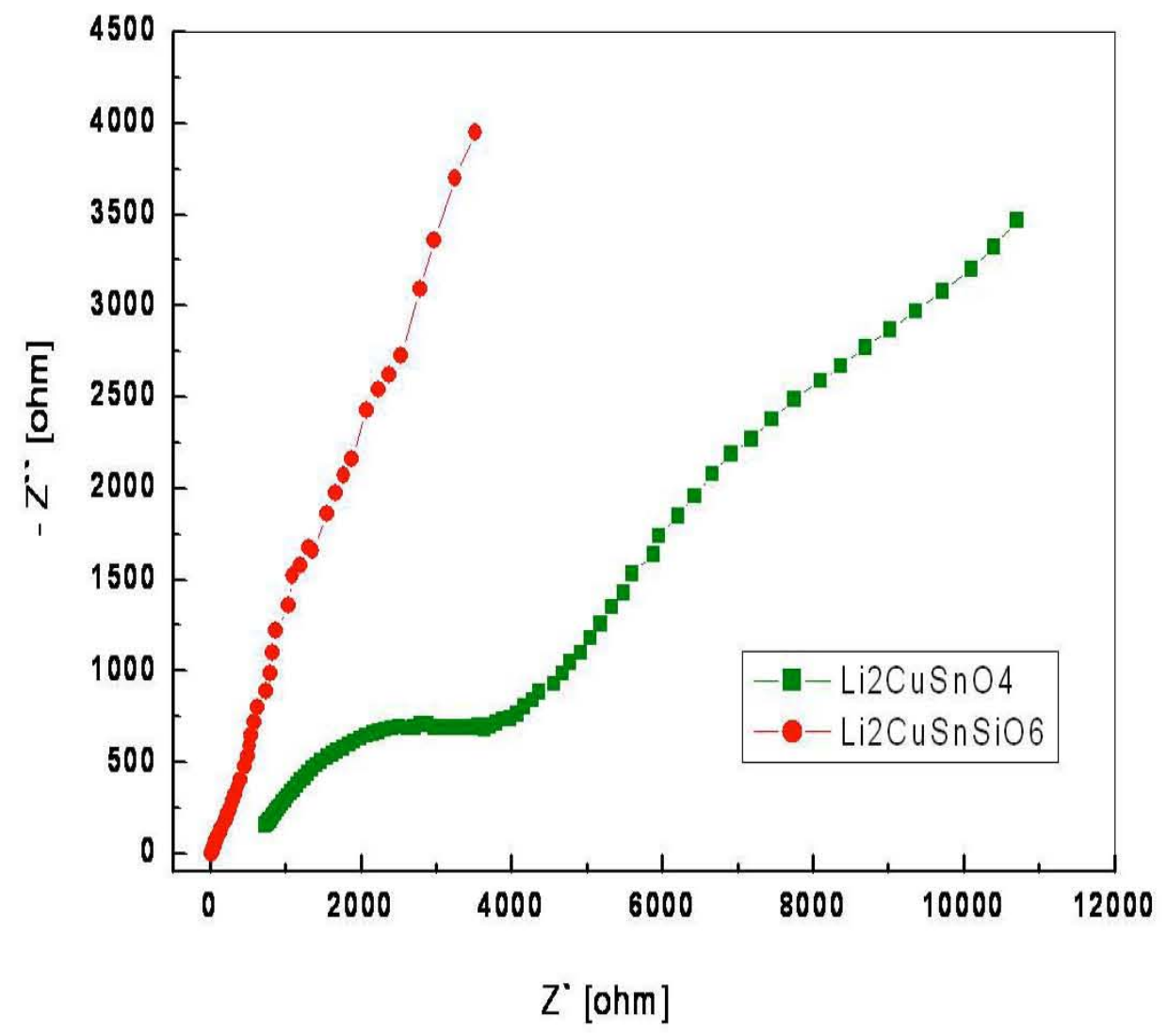

Fig. 4 EIS spectroscopy $\mathrm{Li}_{2} \mathrm{CuSnO}_{4}$ (a) and $\mathrm{Li}_{2} \mathrm{CuSnSiO}_{6}$ (b) Cells. 


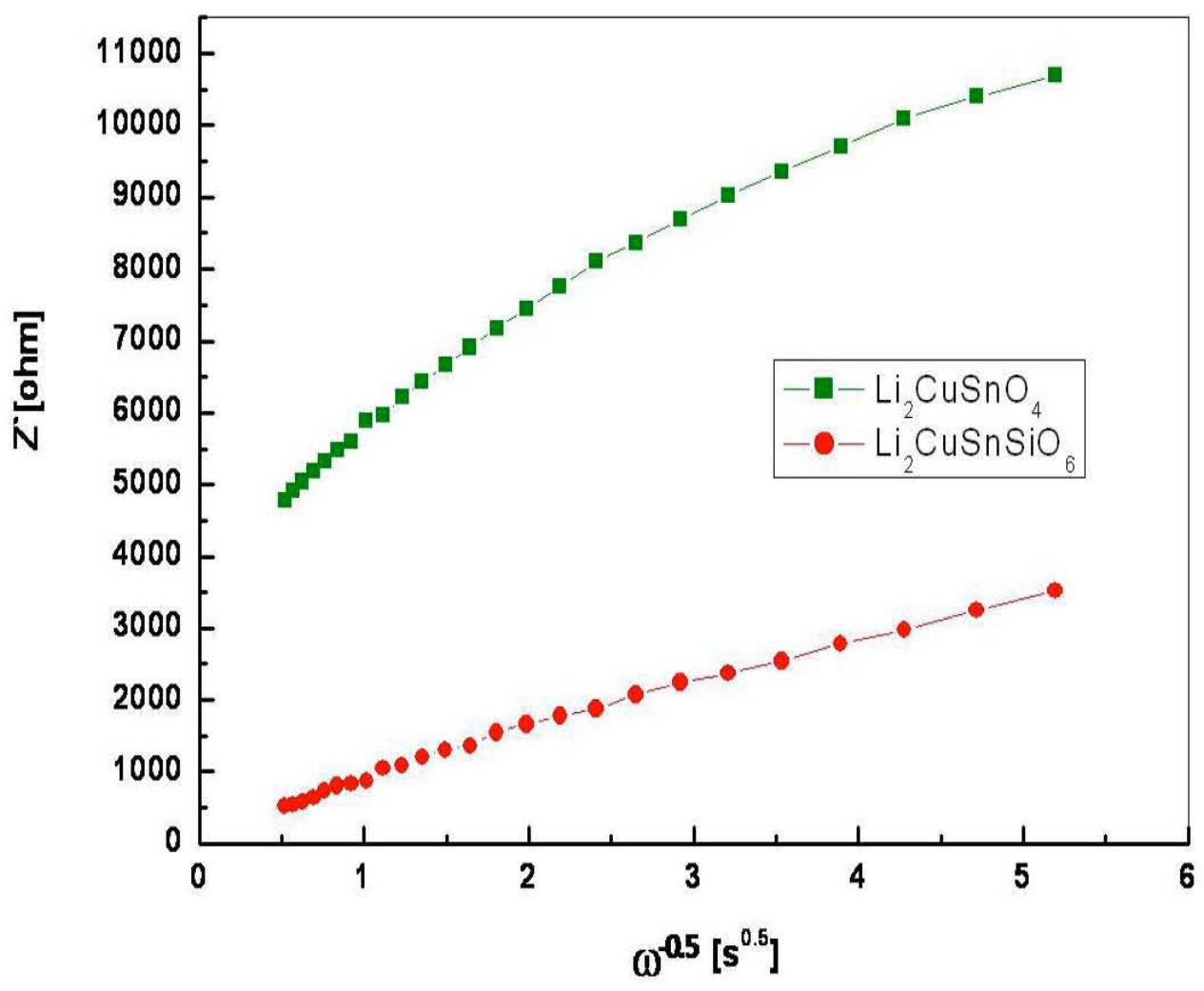

Fig. 5 Relationship between real impedance with the low frequencies for $\mathrm{Li}_{2} \mathrm{CuSnO}_{4}$ (a), $\mathrm{Li}_{2} \mathrm{CuSnSiO}_{6}$ (b) Cells. 

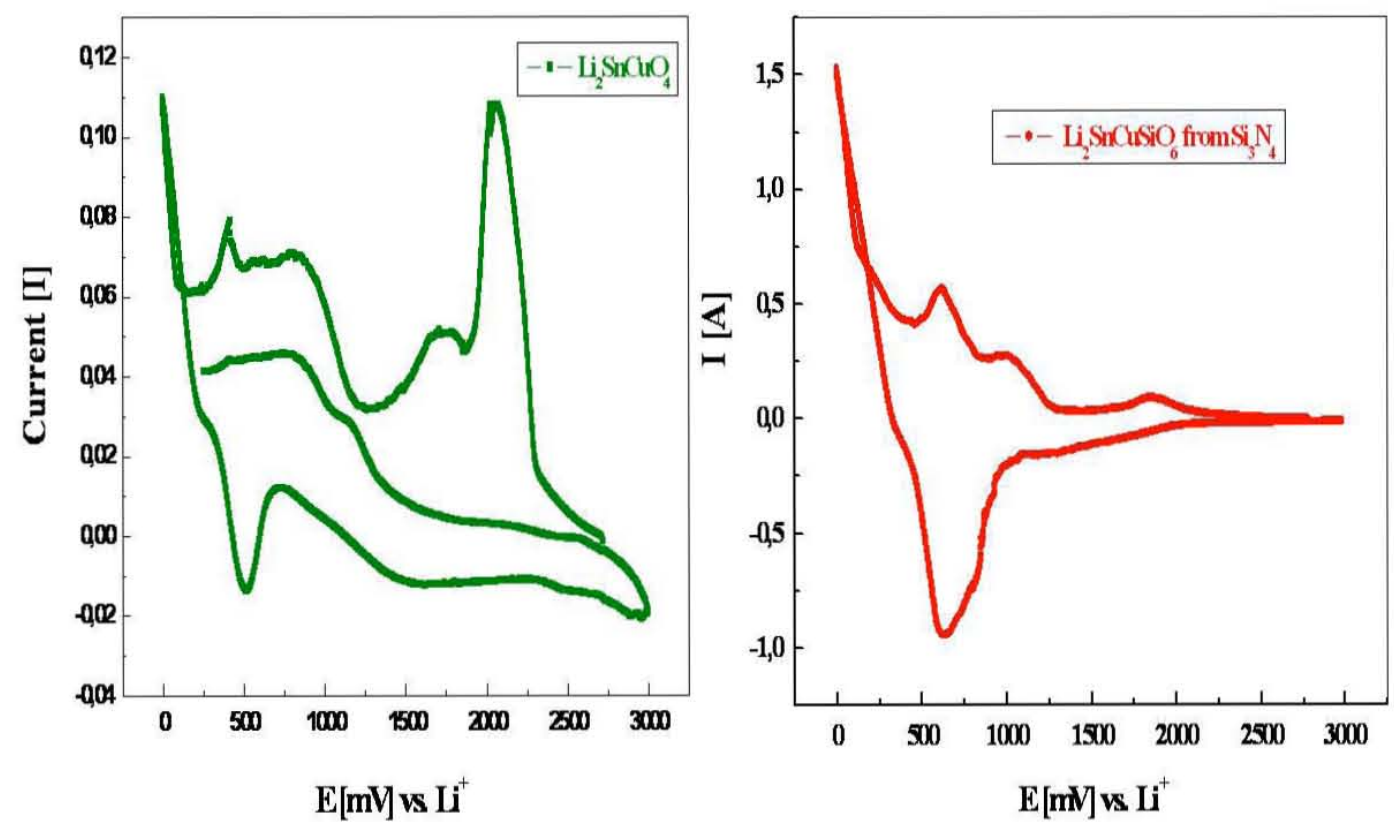

Fig. 6 Cyclic voltammograms of $\mathrm{Li}_{2} \mathrm{CuSnO}_{4}$ (a), $\mathrm{Li}_{2} \mathrm{CuSnSiO}_{6}($ b) cells, scan rate: $0.1 \mathrm{mVs}^{-1}$. 


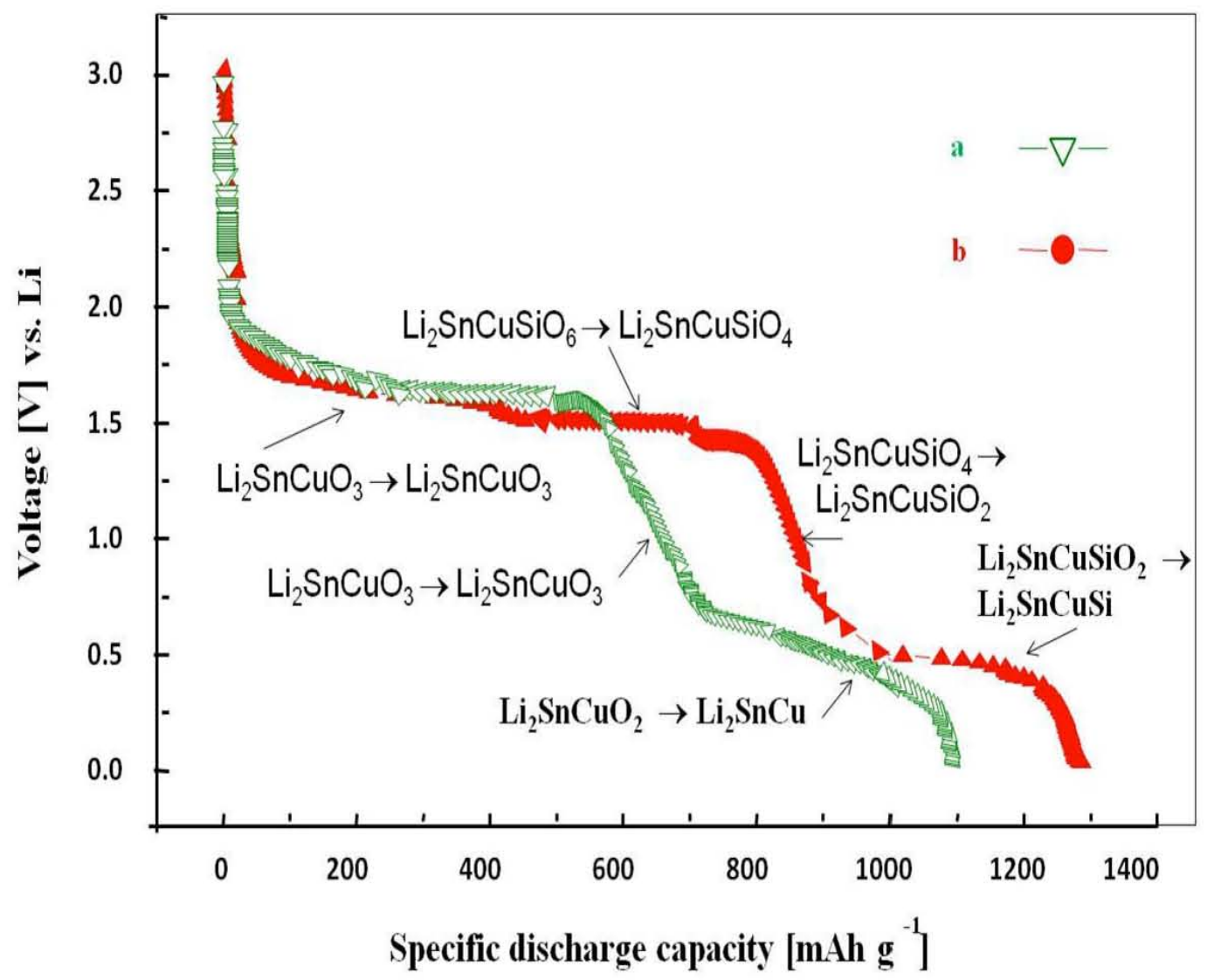

Fig. 7 First discharge voltage- capacity profile of $\mathrm{Li}_{2} \mathrm{CuSnO}_{4}$ (a) $\mathrm{Li}_{2} \mathrm{CuSnSiO}_{6}$ (b) cells. 


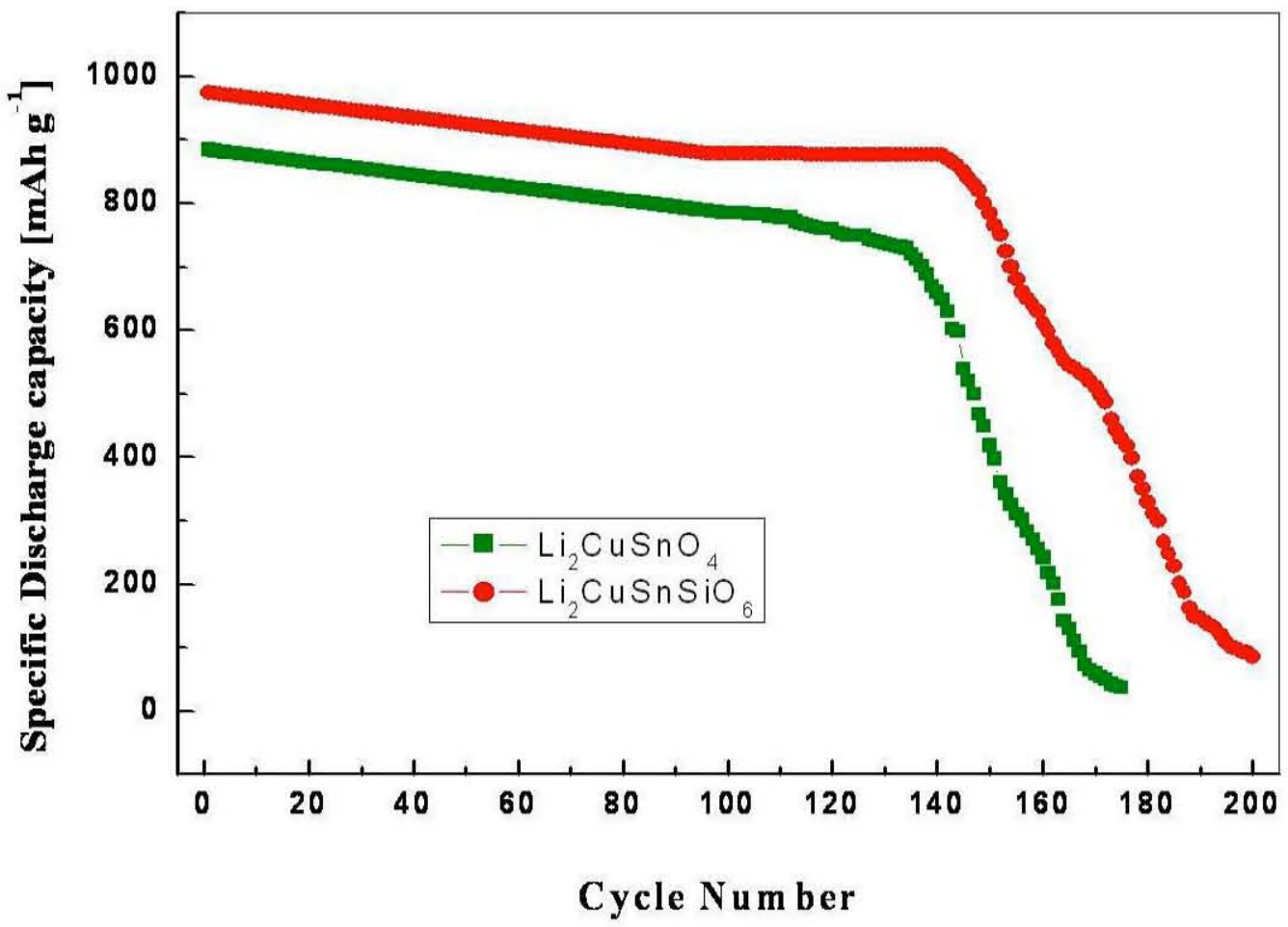

\section{Fig. 8 Cycling performance of $\mathrm{Li}_{2} \mathrm{CuSnO}_{4}$ (a) and $\mathrm{Li}_{2} \mathrm{CuSnSiO}_{6}$ (b) cells.}

